Sri Husnulwati, Tinjauan Hukum Terkait Kampanye Pilkada Ditengah Pademi Covid-19, Halaman 67-76

\title{
TINJAUAN HUKUM TERKAIT KAMPANYE PILKADA DITENGAH PANDEMI COVID-19
}

\author{
Sri Husnulwati \\ Ilmu Hukum, FKIP, Universitas PGRI Palembang \\ E-mail: srihusnulwati05@gmail.com
}

\begin{abstract}
The Government of the Republic of Indonesia has decided to continue the implementation of the Regional Election (pilkada) for governor and deputy governor, regent, and deputy regent, the mayor and deputy mayor process simultaneously in the Covid-19 Pandemic has generated many counter attitudes from various circles. This purpose of this is to review the legal related to the regulatory readiness, especially the simultaneous regional election campaign in the Covid-19 pandemic. The research method used in this research is the legal normative method. The results of this research are, (a) The process of implementing the campaign by the health protocol regulated through PKPU Number 13 of 2020 Article 57, Article 63 and Article 58 paragraph (1) and (2), (b) The campaign materials, it is regulated through PKPU Number 10 of 2020 Article 60 paragraph (2) and (3) PKPU Number 13 of 2020 Article 62, and (c) prohibited activities and sanctions are regulated through PKPU Number 13 of 2020 Article 88B, 88 C paragraph (1) and paragraph (2).
\end{abstract}

Keywords: Law; Campaign; Pilkada; Covid-19

Abstrak

Keputusan Pemerintah Indonesia untuk tetap melaksanakan proses Pemilihan Kepala Daerah (Pilkada) serentak di tengah Pandemi Covid-19 menuai banyak sikap kontra dari berbagai kalangan. Penelitian ini bertujuan untuk meninjau secara hukum terkait kesiapan regulasi khususnya kampanye pilkada serentak di tengah pandemi Covid-19. Metode penelitian yang dipakai pada penelitian ini adalah metode normatif hukum. Adapun hasil dari penelitian ini adalah, (a) Terkait proses pelaksanaan kampanye sesuai dengan protokol kesehatan diatur melalui PKPU Nomor 13 Tahun 2020 Pasal 57, Pasal 63 dan Pasal 58 ayat (1) dan (2), (b) Menyangkut bahan kampanye diatur melalui PKPU Nomor 10 Tahun 2020 Pasal 60 ayat (2) dan (3) serta PKPU Nomor 13 Tahun 2020 Pasal 62, dan (c) kegiatan yang dilarang serta sanksi diatur melalui PKPU Nomor 13 Tahun 2020 pasal 88B, 88C ayat (1) dan ayat (2).

Kata Kunci : Hukum; Kampanye; Pilkada; Covid-19

PENDAHULUAN

Pandemi Covid-19 telah memberikan tekanan yang belum pernah terjadi sebelumnya pada berbagai negara dan wilayah untuk menentukan terus berlangsung atau tidaknya pemilu. Apapun pilihannya, pasti menuai kontroversi. Mencari keputusan yang tepat di antara kedua pilihan ini tidaklah mudah. Apakah pemenuhan kontrak sosial antara sebuah pemerintahan dengan rakyatnya perlu dilakukan dengan membahayakan kesehatan dan keselamatan masyarakat? Atau apakah kekhawatiran akan diperburuknya pandemi akibat berkumpulnya pemilih lebih penting dari pertimbangan lainnya? ${ }^{1}$

\footnotetext{
1 Antonio Spinelli. Kampanye di Tengah New Normal Era: Mampukah Kita Berdamai dengan Pandemi? (Jakarta: IDEA, 2020).
} 
Sri Husnulwati, Tinjauan Hukum Terkait Kampanye Pilkada Ditengah Pademi Covid-19, Halaman 67-76

Data yang dikumpulkan dan diperbaharui secara rutin oleh International IDEA, seperti dapat ditemui pada laman webnya berjudul "Global Overview of COVID-19: Impact on Elections" menunjukkan bahwa, pada saat penulisan makalah ini, paling tidak ada 50 negara dan wilayah-dihadapkan oleh kemungkinan menyebarnya virus dengan menyelenggarakan pemilihan di tengah pandemi - telah memutuskan untuk menunda pemilihan mereka. Namun, sebagian negara dan wilayah telah mengambil keputusan yang berat dan memilih untuk mengambil jalan yang mungkin lebih berbahaya untuk tetap menyelenggarakan pemilihannya sesuai jadwal. $^{2}$

Indonesia menjadi salah satu negara yang tetap "nekat" melaksanakan rangkaian Pilkada Serentak di tengah Pandemi Covid-19. Dalam pandangan politik, keberlangsungan pemilihan 2020 adalah mata air di kemarau ketidakpastian pandemik. Penyelenggaraan pemilihan menjawab semua ikhtiar politik para calon kepala daerah. Usaha komunikasi politik

2 Laman web International IDEA, https://www.idea.int/news-media/ multimediareports/global-overview-covid-19-impactelections. sebelum pandemik Covid-19 akan terjawab dengan sendirinya. Dengan demikian, calon peserta pemilihan bisa mengurangi pengeluaran yang berlebih saat pandemik. Karena anggaran kompetisi politik tidak mencapai surplus maksimal. ${ }^{3}$

Kampanye menjadi bagian penting dalam perhelatan Pilkada Serentak. Dalam kondisi Pandemi Covid-19 seperti saat ini, kepastian penyelenggaraan khususnya mengenai kepastian terkait kampanye yang tetap dalam koridor protokol kesehatan juga sangat diperlukan. Penelitian ini mencoba meninjau regulasi terkait penyelenggaraan kampanye pada kondisi pandemi. Penelitian ini dilakukan dengan metode penelitian hukum yang juga disebut sebagai penelitian hukum empiris.

\section{PEMBAHASAN}

\section{A. Kampanye Sebagai Salah Satu} Tahapan Penting Pilkada

Presiden Republik Indonesia secara resmi menerbitkan Peraturan Pemerintah Pengganti Undang-Undang Perpu) Nomor 2 Tahun 2020 tentang Perubahan Ketiga atas Undang-Undang

3 Adrian Habibi. Upaya Menyelamatkan Pemilihan Umum 2020. Jurnal. Buletin Hukum dan Keadilan Volume 4, Nomor 1 (2020). Doi: 10.15408/adalah.v4i1.15685 
Sri Husnulwati, Tinjauan Hukum Terkait Kampanye Pilkada Ditengah Pademi Covid-19, Halaman 67-76

Nomor 1 Tahun 2015 tentang

Penetapan Peraturan Pemerintah

Pengganti Undang-Undang Nomor 1

Tahun 2014 tentang Pemilihan

Gubernur, Bupati, dan Wali kota

Menjadi Undang- Undang yang ditandatangani pada 4 Mei $2020^{4}$. Perpu ini secara otomatis menjadi payung hukum pelaksanaan Pilkada serentak. Beberapa tahapan yang sempat ditunda akan dapat kembali dilaksanakan dengan peraturan turunan, yakni peraturan KPU. Artinya Pilkada akan tetap berjalan di tengah new normal era, berdampingan dengan wabah covid-19.

Komisi Pemilihan Umum Republik Indonesia mengatakan bahwa ada kemungkinan memutusan untuk melanjutkan tahapan pilkada pada 6 Juni 2020. ${ }^{5}$ Pada Rapat Dengar Pendapat DPR dengan KPU, Bawaslu, DKPP, dan Menteri dalam negeri diambil sebuah ketetapan pencoblosan di tanggal 9 Desember 2020 dan kembali dimulainya tahapan pemilu di

${ }^{4}$ Setkab. 2020. Inilah Perpu Nomor 2 Tahun 2020 Terkait Pemilihan Kepala Daerah Serentak. Diakses melalui website https://setkab.go.id/inilah-perpu-nomor-2tahun-2020-terkait-pemilihan-kepala-daerahserentak/

5 https://news.detik.com/berita/d5019094/kpu-tahapan-pilkada-dimulai-6-juni2020-tapi-ada-syarat-dan-kondisinya, 2020. tanggal 15 Juni $2020 .{ }^{6}$ Ketua KPU RI, Arief Budiman mengatakan bahwa ada dua syarat dari insitusi tersebut untuk melanjutkan jalannya tahapan pemilu yang tertunda, yaitu tidak lagi diterapkannya pembatasan sosial berskala besar (PSBB). Syarat kedua adalah tidak lagi diberlakukannya status tanggap darurat. Kondisi tersebut masih dapat berubah melihat situasi yang berkembang, KPU mengatakan siap untuk melakukan pemungutan suara pada Desember 2020, Maret 2021, atau September $2021 .{ }^{7}$

KPU sendiri menyebut perlunya hand sanitizer, masker, dan pengurangan jumlah pemilih yang semula 800 per TPS menjadi 400 per TPS sebagai bagian dari protokol kesehatan pada penyelenggaraan Pilkada. Pengurangan jumlah pemilih artinya penambahan jumlah TPS atau perluasan area TPS dan penambahan bilik suara. Penambahan jumlah TPS artinya penambahan logistik atau penambahan jumlah anggaran. Pada kesempatan lain, Ketua KPU mengatakan bahwa diperlukan dana

\footnotetext{
${ }^{6} \mathrm{http}: / /$ www.dpr.go.id/berita/detail/id/28851/t/ DPR+dan+Pemerintah+Sepakat+Pilkada+Sere ntak+9+Desem ber+2020, 2020.

https://nasional.kompas.com/read/2020/05/27/2 2081061/kpu-pelaksanaan-pilkada-2020-harussesuai-protokol- , 2020.
} 
Sri Husnulwati, Tinjauan Hukum Terkait Kampanye Pilkada Ditengah Pademi Covid-19, Halaman 67-76

tambahan sebesar 535,9 miliar rupiah untuk pelaksanaan Pilkada 2020 pada 9 Desember mendatang di 270 daerah. Dana tambahan berkenaan dengan pilkada yang dihelat di tengah pandemi virus corona (Covid-19). ana tambahan itu, kata Arief, bakal dipakai membeli alat pelindung diri (APD) untuk para petugas penyelenggara pemilu. Di antaranya berupa masker, baju pelindung diri, sarung tangan, pelindung wajah, tong air, sabun cuci tangan, tisu hingga cairan disinfektan. ${ }^{8}$

KPU sendiri menyebut perlunya hand sanitizer, masker, dan pengurangan jumlah pemilih yang semula 800 per TPS menjadi 400 per TPS sebagai bagian dari protocol kesehatan pada penyelenggaraan Pilkada. Pengurangan jumlah pemilih artinya penambahan jumlah TPS atau perluasan area TPS dan penambahan bilik suara. Penambahan jumlah TPS artinya penambahan logistik atau penambahan jumlah anggaran. Pada kesempatan lain, Ketua KPU mengatakan bahwa diperlukan dana tambahan sebesar 535,9 miliar rupiah untuk pelaksanaan Pilkada 2020 pada 9 Desember mendatang di 270 daerah. 25

\footnotetext{
8 Mohammad Wildan Akbar. Kampanye di Tengah New Normal Era: Mampukah Kita Berdamai dengan Pandemi? (Researchgate, 2020)
}

Dana tambahan berkenaan dengan pilkada yang dihelat di tengah pandemi virus corona (Covid-19). ana tambahan itu, kata Arief, bakal dipakai membeli alat pelindung diri (APD) untuk para petugas penyelenggara pemilu. Di antaranya berupa masker, baju pelindung diri, sarung tangan, pelindung wajah, tong air, sabun cuci tangan, tisu hingga cairan disinfektan. ${ }^{9}$

Merujuk pada laman Direktorat Jenderal Administrasi Kewilayahan Kementerian Dalam Negeri, bahwa rapat kerja dan rapat dengar pendapat yang dihadiri Menteri Dalam Negeri, Komisi Pemilihan Umum (KPU), Badan Pengawas Pemilihan Umum (Bawaslu), Dewan Kehormatan Penyelenggara Pemilu (DKPP), dan Komisi II Dewan Perwakilan Rakyat (DPR) RI di ruang rapat Komisi II DPR RI menyepakati bahwa Pemilihan Kepala Daerah (Pilkada) serentak 2020 tetap dilaksanakan sesuai jadwal dengan penegakan disiplin dan sanksi hukum terhadap pelanggaran protokol kesehatan $^{10}$.

https://www.cnnindonesia.com/nasional/20200 527191056-32-507429/kpu-minta-danapilkada-2020- ditambah-rp535-m-untuk-beliapd , 2020 .

10 Oktavira, Bernadetha Aurelia. 2020.

"Bentuk Kampanye Pilkada yang Dilarang di Tengah Pandemi Covid-19.” Online. Dikutip dari website 
Sri Husnulwati, Tinjauan Hukum Terkait Kampanye Pilkada Ditengah Pademi Covid-19, Halaman 67-76

Dalam kondisi Pandemi Covid-

19 seperti saat ini tentu banyak pertanyaan muncul, khususnya mengenai bagaimana regulasi terkait penyelenggaraan kampanye pada pilkada serentak. Pada pembahasan berikutnya, penulis akan menguraikan tinjauan regulasi berdasarkan beberapa kategori seperti pelaksanaan secara umum, bahan kampanye serta kegiatan yang dilarang sesuai dengan peraturan yang berlaku.

\section{B. Pelaksanaan Kampanye}

Merujuk pada Peraturan Komisi Pemilihan Umum (PKPU) No. 13 Tahun 2020 khususnya pasal 57, dijelaskan bahwa Adapun metode pelaksanaan kampanye Pilkada 2020 diantaranya adalah sebagai berikut :

1. Pertemuan terbatas;

2. Pertemuan tatap muka dan dialog;

3. Debat publik atau debat terbuka antar-pasangan calon;

4. Penyebaran bahan Kampanye kepada umum;

5. Pemasangan Alat Peraga Kampanye;

6. Penayangan Iklan Kampanye di media massa cetak, media massa

https://www.hukumonline.com/klinik/detail/ula $\underline{\text { san/lt5f75cf4f5da16/bentuk-kampanye- }}$ pilkada-yang-dilarang-di-tengah-pandemicovid-19 elektronik, Media Sosial, dan/atau Media Daring; dan/atau

7. Kegiatan lain yang tidak melanggar larangan Kampanye dan ketentuan peraturan perundang-undangan.

Terkait dengan kegiatan lain, yang dimaksud dalam aturan dimaksud, diatur kembali dalam pasal 63 yang berbunyi bahwa, "kegiatan lain yang tidak melanggar larangan kampanye dan ketentuan peraturan perundangundangan sebagaimana dimaksud dalam Pasal 57 huruf g dilaksanakan dalam bentuk Kampanye melalui Media Sosial dan Media Daring."

Jadi, jika merujuk Peraturan KPU No 13 Tahun 2020, maka secara umum peserta Pilkada Serentak tetap dapat melaksanakan proses kampanye dengan metode yang sama namun terbatas dan dengan protocol Kesehatan yang ketat. Selain itu, proses kampanye diharapkan lebih banyak menggunakan media sosial dan internet.

Terkait dengan metode kampanye sebenarnya ditegaskan bahwa sebaiknya partai politik atau gabungan partai politik, pasangan calon, tim kampanye, dan/atau pihak lain lebih mengutamakan metode kampanye pertemuan terbatas dan pertemuan 
Sri Husnulwati, Tinjauan Hukum Terkait Kampanye Pilkada Ditengah Pademi Covid-19, Halaman 67-76

tatap muka dan dialog melalui media sosial dan media daring. Hal ini diatur pada Pasal 58 ayat (1) Peraturan KPU Nomor 13 Tahun 2020.

Jika terjadi kendala dalam pelaksanaan secara daring terkait pertemuan terbatas dan pertemuan tatap muka serta dialog, maka pada Pasal 58 ayat (2) telah diatur dengan ketentuan sebagai berikut :

a. Dilaksanakan dalam ruangan atau Gedung;

b. Membatasi jumlah peserta maksimal 50 orang dan memperhitungkan jaga jarak minimal 1 meter antar peserta kampanye, serta dapat diikuti melalui media sosial dan media daring;

c. Wajib menggunakan alat pelindung diri minimal berupa masker yang menutupi hidung dan mulut hingga dagu;

d. Menyediakan sarana sanitasi yang memadai minimal berupa fasilitas cuci tangan dengan air mengalir dan sabun, dan/atau cairan antiseptic berbasis alcohol (handsanitizer); dan

e. Wajib mematuhi ketentuan mengenai status penanganan COVID-19 pada daerah pemilihan yang ditetapkan oleh pemerintah daerah dan/atau gugus tugas percepatan penanganan COVID-19.

\section{Bahan Kampanye}

Selain mengatur mengenai pelaksanaan kampanye, KPU juga telah mengatur tentang bahan kampanye yang dipakai selama kampanye. Terkait dengan bahan kampanye masih merujuk pada Peraturan KPU Nomor 10 Tahun 2020 tentang Perubahan atas Peraturan Komisi Pemilihan Umum Nomor 6 Tahun 2020 Tentang Pelaksanaan Pemilihan Gubernur dan Wakil Gubernur, Bupati dan Wakil Bupati, dan/atau Wali Kota dan Wakil Walikota Serentak Lanjutan dalam Kondisi Bencana Non Alam Corona Virus Disease 2019 (COVID-19). Penyebaran bahan kampanye kepada umum dilakukan dengan menerapkan protokol kesehatan sesuai pada Pasal 60 ayat (2), yaitu :

a. Sebelum dibagikan, bahan kampanye yang akan dibagikan harus dalam keadaan bersih, dibungkus dengan bahan yang tahan terhadap zat cair, dan telah disterilisasi;

b. Petugas yang membagikan bahan kampanye menggunakan masker yang menutupi hidung dan mulut hingga dagu dan sarung tangan; dan

c. Pembagian bahan kampanye tidak menimbulkan kerumunan. 
Sri Husnulwati, Tinjauan Hukum Terkait Kampanye Pilkada Ditengah Pademi Covid-19, Halaman 67-76

Selain itu, sebagai bagian dari

proses kampanye serta membantu pengadaan sarana mengantisipasi penyebaran virus Covid-19, maka sesuai isi dari Peraturan KPU Nomor 10 Tahun 2020 Pasal 60 ayat (2) disebutkan bahwa, selain Bahan Kampanye yang telah ditentukan dalam Peraturan KPU yang mengatur mengenai Kampanye Pemilihan, Partai Politik atau Gabungan Partai Politik, Pasangan Calon dan/atau Tim Kampanye dapat membuat dan mencetak Bahan Kampanye berupa alat pelindung diri yang terdiri atas :

a. Masker;

b. Sarung tangan;

c. Pelindung wajah (face shield); dan/atau

d. Cairan antiseptic berbasis alcohol (handsanitizer).

Terkait dengan penayangan Iklan Kamapanye tetap dilaksanakan selama 14 (empat belas) hari sebelum dimulainya masa tenang.

\section{Kegiatan Yang Dilarang}

Pada dasarnya, terdapat beberapa kegiatan yang dilarang dilaksanakan baik oleh partai politik atau gabungan partai politik, pasangan calon, tim kampanye dan/atau pihak lain sesuai dengan ketentuan yang diatur dalam Pasal 88B PKPU Nomor 13 Tahun 2020 yaitu :
(1) Pasangan Calon, Partai Politik atau Gabungan Partai Politik pengusul, Tim Kampanye, dan/atau pihak lain dilarang melakukan iring-iringan dan menghadirkan massa pendukung di dalam dan di luar ruangan pelaksanaan pengundian nomor urut Pasangan Calon.

(2) Pasangan Calon, Partai Politik atau Gabungan Partai Politik pengusul, Tim Kampanye, dan/atau pihak lain yang melanggar ketentuan sebagaimana dimaksud pada ayat (1), dikenai sanksi berupa peringatan tertulis pada saat terjadinya pelanggaran oleh Bawaslu Provinsi atau Bawaslu Kabupaten/Kota.

(3) Dalam hal Pasangan Calon, Partai Politik atau Gabungan Partai Politik pengusul, Tim Kampanye, dan/atau pihak lain telah diberikan peringatan tertulis sebagaimana dimaksud pada ayat (2) tetap melakukan pelanggaran terhadap larangan sebagaimana dimaksud pada ayat (1), Bawaslu Provinsi atau Bawaslu Kabupaten/Kota memberikan rekomendasi kepada KPU Provinsi atau KPU Kabupaten/Kota untuk mengenakan sanksi administrasi.

(4) KPU Provinsi atau KPU Kabupaten/Kota wajib melaksanakan rekomendasi Bawaslu Provinsi atau Bawaslu Kabupaten/Kota sebagaimana dimaksud pada ayat (3) dengan mengenakan 
Sri Husnulwati, Tinjauan Hukum Terkait Kampanye Pilkada Ditengah Pademi Covid-19, Halaman 67-76

sanksi administrasi sebagai berikut:

a. apabila terdapat 1 (satu) atau beberapa Pasangan Calon yang melakukan pelanggaran terhadap larangan sebagaimana dimaksud pada ayat (1), maka pengundian nomor urut Pasangan Calon yang bersangkutan dilakukan penundaan sampai dengan Pasangan Calon membuat dan menyampaikan surat pernyataan yang menyatakan tidak akan melakukan pelanggaran terhadap larangan sebagaimana dimaksud pada ayat (1) kepada KPU Provinsi atau KPU Kabupaten/Kota; atau

b. apabila seluruh Pasangan Calon melakukan pelanggaran terhadap larangan sebagaimana dimaksud pada ayat (1), maka pengundian nomor urut Pasangan Calon dilakukan penundaan sampai dengan masingmasing Pasangan Calon membuat dan menyampaikan surat pernyataan yang menyatakan tidak akan melakukan pelanggaran terhadap larangan sebagaimana dimaksud pada ayat (1) kepada KPU Provinsi atau KPU Kabupaten/Kota.

(5) Pengundian nomor urut Pasangan Calon yang ditunda sebagaimana dimaksud pada ayat (4) dilakukan paling lambat 1 (satu) Hari setelah jadwal pengundian nomor urut Pasangan Calon sebagaimana diatur dalam peraturan KPU yang mengatur mengenai tahapan, program, dan jadwal penyelenggaraan Pemilihan.

(6) Pengundian nomor urut Pasangan Calon yang ditunda sebagaimana dimaksud pada ayat (4) huruf a dilakukan dengan mengambil nomor urut yang belum diundi.

Jika merujuk pada pasal $88 \mathrm{C}$ ayat (1), maka Partai Politik atau Gabungan Partai Politik, Pasangan Calon, Tim Kampanye, dan/atau pihak lain dilarang melaksanakan kegiatan lain dalam bentuk :

a. Rapat umum;

b. Kegiatan kebudayaan berupa pentas seni, panen raya, dan/atau konser music;

c. Kegiatan olahraga berupa gerak jalan santai, dan/atau sepeda santai;

d. Perlombaan;

e. Kegiatan sosial berupa bazar dan/atau donor darah; dan/atau

f. Peringatan hari ualng tahun Partai Politik.

Apabila ketentuan pada pasal 88C ayat (1) dilanggar, maka bentuk sanksi yang akan diterima sesuai 
Sri Husnulwati, Tinjauan Hukum Terkait Kampanye Pilkada Ditengah Pademi Covid-19, Halaman 67-76

dengan ketentuan pada pasal $88 \mathrm{C}$ ayat

(2) yaitu berupa : Peringatan tertulis oleh Bawaslu Provinsi atau Bawaslu Kabupaten/Kota pada saat terjadinya pelanggaran; dan/atau Penghentian dan pembubaran kegiatan kampanye ditempat terjadinya pelanggaran oleh Bawaslu Provinsi atau Bawaslu Kabupaten/Kota, apabila tidak melaksanakan peringatan tertulis sebagaimana dimaksud dalam huruf a dalam waktu 1 (satu) jam sejak diterbitkan peringatan tertulis.

\section{KESIMPULAN}

Terkait proses pelaksanaan kampanye masih menggunakan pertemuan tatap muka walaupun secara terbatas dengan dibantu melalui media sosial dan media daring. Hal ini jelas diatur melalui PKPU Nomor 13 Tahun 2020 Pasal 57, Pasal 63, dan Pasal 58 ayat (1). Jikapun terjadi kendala telah diatur pula pada Pasal 58 ayat (2) PKPU Nomor 13 Tahun 2020.

Menyangkut bahan kampanye, terdapat anjuran dan larangan yang merujuk pada disiplin protokol kesehatan baik menjaga kebersihan bahan kampanye, penggunaan masker dan menjaga jarak saat pembagian masker. Hal ini telah diatur melalui
PKPU Nomor 10 Tahun 2020 Pasal 60 ayat (2) dan (3) serta PKPU Nomor 13 Tahun 2020 Pasal 62.

Kegiatan yang dilarang telah diatur, terutama merujuk pada kegiatan yang dapat melanggar protokol Kesehatan seperti penggunaan masker dan menghindari kerumunan. Hal ini jelas telah diatur dalam Pasal 88B serta 88C ayat (1) PKPU Nomor 13 Tahun 2020. Terkait sanksi walaupun belum mencantumkan terkait diskulaifikasi calon namun telah dicantumkan dalam Pasal 88C ayat (2) PKPU Nomor 13 Tahun 2020.

\section{DAFTAR PUSTAKA}

Adrian Habibi. Upaya Menyelamatkan Pemilihan Umum 2020. Jurnal. Buletin Hukum dan Keadilan Volume 4, Nomor 1 (2020). Doi: 10.15408/adalah.v4i1.15685

Antonio Spinelli. Kampanye di Tengah New Normal Era: Mampukah Kita Berdamai dengan Pandemi? Jakarta: IDEA, 2020.

https://news.detik.com/berita/d5019094/kpu-tahapan-pilkadadimulai-6-juni-2020-tapi-adasyarat-dan-kondisinya, 2020. http://www.dpr.go.id/berita/detail/id/28 851/t/DPR+dan+Pemerintah+Sep akat+Pilkada+Serentak+9+Dese m ber+2020, 2020.

https://nasional.kompas.com/read/2020 /05/27/22081061/kpu- 
Sri Husnulwati, Tinjauan Hukum Terkait Kampanye Pilkada Ditengah Pademi Covid-19, Halaman 67-76

pelaksanaan-pilkada-2020-harus-

sesuai-protokol- , 2020.

https://www.cnnindonesia.com/nasiona

1/20200527191056-32-

507429/kpu-minta-dana-pilkada-

2020- ditambah-rp535-m-untuk-

beli-apd , 2020.

Laman web International IDEA, https://www.idea.int/news-media/ multimedia-reports/global-

overview-covid-19-impact-

elections.

Mohammad Wildan Akbar. Kampanye

di Tengah New Normal Era:

Mampukah Kita Berdamai dengan Pandemi? Researchgate, 2020.

Oktavira, Bernadetha Aurelia. 2020.

"Bentuk Kampanye Pilkada yang

Dilarang di Tengah Pandemi

Covid-19."

Online.https://www.hukumonline .com/klinik/detail/ulasan/lt5f75cf

4f5da16/bentuk-kampanye-

pilkada-yang-dilarang-di-tengah-

pandemi-covid-19

Setkab. 2020. Inilah Perpu Nomor 2

Tahun 2020 Terkait Pemilihan Kepala Daerah Serentak. Diakses melalui website

https://setkab.go.id/inilah-perpu-

nomor-2-tahun-2020-terkait-

pemilihan-kepala-daerah-

$\underline{\text { serentak/ }}$ 